\title{
ORGANIZATIONAL INNOVATION CONCEPTS IN SLOVENIAN MANUFACTURING COMPANIES
}

\author{
PALCIC, I., OJSTERSEK, R. \& BUCHMEISTER, B.
}

Abstract: The main purpose of this manuscript is to map the adoption of selected innovative organizational concepts in manufacturing companies. A further objective of our research is to find out how different organizational concepts are represented in different manufacturing company's types. Based on a sample of 118 Slovenian manufacturing companies collected through the 2018-19 European Manufacturing Survey edition, results give information about the most used organizational concepts, their utilization degree, planned use and average year of implementation. The use of organizational innovation concepts is also heavily dependent on the company characteristics in terms of size, technological intensity, supplier or OEM status etc.

Key words: Manufacturing company, Organizational innovation concept, European manufacturing survey, Company characteristics.
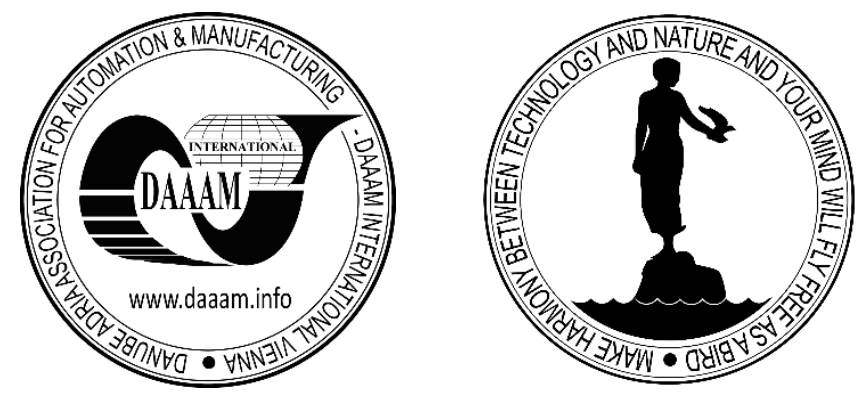

Authors' data: Prof. Dr. Sc. Palcic, I[ztok]*; M. Sc. Ojstersek, R[obert]*, Prof. Dr. Sc. Buchmeister, B[orut] *, * University of Maribor, Faculty of Mechanical Engineering, Laboratory for Production Management, Smetanova 17, SI - 2000, Maribor, Slovenia, iztok.palcic@um.si, robert.ojstersek@um.si, borut.buchmeister@um.si

This Publication has to be referred as: Palcic, I[ztok]; Ojstersek, R[obert] \& Buchmeister, B[orut] (2020). Organizational Innovation Concepts in Slovenian Manufacturing Companies, Chapter 05 in DAAAM International Scientific Book 2020, pp.061-078, B. Katalinic (Ed.), Published by DAAAM International, ISBN 9783-902734-27-3, ISSN 1726-9687, Vienna, Austria

DOI: $10.2507 /$ daaam.scibook.2020.05 


\section{Introduction}

Organizational innovation has been an important and interesting research area for years, although it has been pointed out several times that innovation is still sometimes more synonymous with product innovation or technical innovation than process or organizational or managerial innovation (Galego et al., 2012). Although organizational innovation is considered an important contributor and trigger to the product innovation, and ultimately to company success, organizational or non-technical innovation needs further and deeper understanding (Kocijančič et al., 2013). Damanpour (2014) argues that there is not enough research or papers that identify and measure the organizational innovation in companies.

The main purpose of this manuscript is to map the adoption of organizational innovation in manufacturing companies through the lens of selected organizational concepts and their use. Additionally to that, we present degree of use and planned implementation of selected organizational innovation concepts. We have analysed organizational concepts use regarding company size, technological intensity and $\mathrm{OEM} /$ supplier status. Based on that, the structure of the remainder of the manuscript is as follows. Section 2 gives a short introduction on organizational innovation. Section 3 describes used research methodology. Section 4 comprises the results of the analysis and discussion, while the conclusions are presented in section 5 .

\section{Organizational innovation concepts}

OECD Oslo Manual from 2005 defines an organizational innovation as the implementation of a new organizational method in the company's business practices, workplace organization or external relations. Organizational innovations are intended to increase company performance by reducing administrative and transaction costs, improving work-place satisfaction (and thus labour productivity), gaining access to non-tradable assets (such as non-codified external knowledge) or reducing costs of supplies. OECD Oslo Manual (2005) also includes in its conceptualization of management innovation the introduction of new marketing innovations. In the new version of OECD Manual from 2018 organizational innovations are subsumed under one type of business process innovation (administration and management) that includes activities that can involve what previously was described as organizational innovation, such as strategic management (business practices and external relations) and human resource management (workplace organization in the third edition).

In our research, we followed a typology of organizational innovations by Armbruster et al. (2008), that differentiates organizational innovation into structural and procedural organizational innovations on one hand, and into intra-organizational and inter-organizational organizational innovation on the other hand. Structural organizational innovations influence, change and improve responsibilities, accountability, command lines and information flows as well as the number of hierarchical levels, the divisional structure of functions or the separation between line 
and support functions. Procedural organizational innovations affect the routines, processes and operations of a company. Thus, these innovations change or implement new procedures and processes within the company, such as simultaneous engineering or zero buffer rules.

\begin{tabular}{|c|c|c|c|}
\hline & & \multicolumn{2}{|c|}{ Focus of organizational innovation } \\
\hline & & Intra-organizational & Inter-organizational \\
\hline \multirow{2}{*}{ 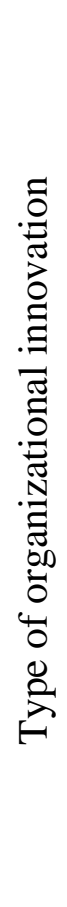 } & 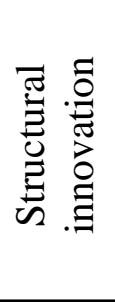 & $\begin{array}{c}\text { Cross-functional teams } \\
\text { Decentralisation of planning, } \\
\text { operating and controlling functions } \\
\text { Manufacturing cells or segments } \\
\text { Reduction of hierarchical levels } \\
\ldots\end{array}$ & $\begin{array}{c}\text { Cooperation / networks / alliances } \\
\text { (R\&D, production, service, sales, } \\
\text { etc.) } \\
\text { Make or buy / outsourcing } \\
\text { Off-shoring / relocation }\end{array}$ \\
\hline & 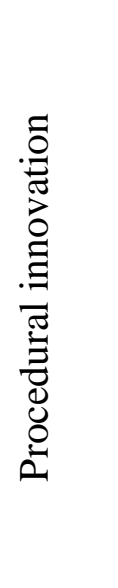 & $\begin{array}{c}\text { Team work in production } \\
\text { Job enrichment / job enlargement } \\
\text { Simultaneous engineering / } \\
\text { concurrent engineering } \\
\text { Continuous improvement process / } \\
\text { Kaizen } \\
\text { Quality circles } \\
\text { Quality audits / certification (ISO) } \\
\text { Environmental audits (ISO) } \\
\text { Zero-buffer principles (KANBAN) } \\
\text { Preventive maintenance } \\
\ldots\end{array}$ & $\begin{array}{c}» J \text { ust-in-time« (to customers, with } \\
\text { suppliers) } \\
\text { Single / dual sourcing } \\
\text { Supply chain management } \\
\text { Customer quality audits }\end{array}$ \\
\hline
\end{tabular}

Fig. 1. Types of organizational innovation

Organizational innovation can be further differentiated along an intraorganizational and inter-organizational dimension. Intra-organizational innovations occur within company, inter-organizational innovations include new organizational structures or procedures beyond a company's boundaries. These comprise new organizational structures in an organization's environment, such as R\&D cooperation with customers, just-in-time processes with suppliers or customers, supply chain management practices with suppliers or customer quality audits. Intra-organizational innovations may concern particular departments or functions or may affect the overall structure and strategy of the company as a whole (Armbruster et al., 2008).

\section{Research methodology}

The data for our research is obtained from the European Manufacturing Survey (EMS), a survey organized by a consortium of European research institutes and universities. EMS is a survey on the diffusion of advanced production technologies and organizational concepts in the European manufacturing industry. It investigates technological and non-technological innovation in European industries. 
Palcic, I.; Ojstersek, R. \& Buchmeister, B.: Organizational Innovation Concepts in ...

It focuses on fields such as technical modernisation of value adding processes, introduction of innovative organizational concepts, international offshoring/outsourcing and backshoring of production and R\&D activities, and new business models for complementing the product portfolio with innovative services. EMS includes at company level detailed information on innovation input, including R\&D expenditure, innovation output such as the introduction of new products to the market, the qualification structure of the employees, the degree of utilization of a number of advanced production technologies, and a number of control variables, such as company size, exports, the position of the company in the value chain, or characteristics of the main product and of the production process. In addition, data are collected on performance indicators such as productivity, flexibility, quality and returns (Dachs et al., 2019). The main objectives of EMS project are to find out more about the use of manufacturing and information technologies, new organizational approaches in manufacturing and the implementation of best management practices.

EMS is organized by a consortium of research institutions coordinated by the Fraunhofer Institute for Systems and Innovation Research (ISI), and takes place every three years. EMS is organized as a paper-based or electronic survey at a company level. The core questionnaire has six pages, with additional national specific questions the questionnaire may take up to 8 pages. It targets a random sample of manufacturing establishments with at least 20 employees (NACE codes from 10 to 33 in code C "Manufacturing"). The responding companies, therefore, present a multi-country cross-section of the main manufacturing industries, including producers of rubber and plastics, metal works, mechanical engineering, electrical engineering, textile and others. For preparing multinational analysis, the national data undergo a joint harmonisation procedure. Regarding the submission process, the respondent is always a top-level informant - production manager, plant manager, industrial director or Chief Executive Officer (CEO), depending on the size of each company - with a global perspective (or access to information) about the industrial and business requirements. Additionally, random phone calls to non-responsive plants are usually made to improve the response rate (Sartal et al., 2017).

The beginnings of EMS date to year 2000, when Germany and Switzerland started with a pilot study in their countries. The first official EMS round was conducted in 2003/2004 as a survey in 9 European countries. The survey covered Austria, Croatia, France, Germany, United Kingdom, Italy, Slovenia, Switzerland and Turkey. In the year 2006/2007 a new survey was conducted in even more European countries, where Greece, Netherlands and Spain joined the project. The next edition of the EMS was carried out in 2009. The survey became global as China and Russia joined the project team as well as Denmark and Finland. Unfortunately, we did not receive data from Turkey and United Kingdom, therefore 12 countries provided data. The fourth edition of EMS started in 2012 and finished in 2013. Our family grew to 17 countries as Czech Republic, Sweden and Brazil joined the survey. China, Russia and Brazil did not produce any results and left the consortium, as well as Turkey. Italy, France and United Kingdom changed project partner within their country. 
This chapter is based on data from mostly sixth EMS round and partly fifth EMS round. The fifth edition of EMS is from 2015/16. Serbia joint our consortium, unfortunately many countries did not produce the results: Italy, Finland, United Kingdom, Czech Republic, Sweden. France and Portugal produced survey with very low returns. By the end of 2018 Czech Republic changed partner and we welcomed new partners from Lithuania, Slovakia and Norway. The last round was finished in Slovenia in March 2019.

\subsection{Basic characteristics of Slovenian EMS}

Our research is based on EMS data from Slovenian subsample from the last two EMS rounds, namely EMS 2015 and EMS 2018. The response rate in Slovenia has always been between 10 and $15 \%$. In 2015 we sent 732 questionnaires and received 90 responses (12.3\% response rate). In 2018 we sent out 778 questionnaires and received 119 filled-in questionnaires (15.3\% response rate).

Manufacturing companies in our research fall into the following NACE classification divisions:

- 22 - Manufacture of rubber and plastic products;

- 23 - Manufacture of other non-metallic mineral products;

- 24 - Manufacture of basic metals;

- 25 - Manufacture of fabricated metal products, except machinery and equipment;

- 26 - Manufacture of computer, electronic and optical products;

- 27 - Manufacture of electrical equipment;

- 28 - Manufacture of machinery and equipment n.e.c.;

- 29 - Manufacture of motor vehicles, trailers and semi-trailers;

- 30 - Manufacture of other transport equipment;

- 32 - Other manufacturing.

\begin{tabular}{|c|c|c|c|c|}
\hline $\begin{array}{c}\text { NACE } \\
\text { code C }\end{array}$ & $\begin{array}{c}\text { Number of } \\
\text { companies in } \\
\text { database }\end{array}$ & $\begin{array}{c}\text { Number of } \\
\text { responses }\end{array}$ & $\begin{array}{c}\text { Response rate } \\
\text { NACE division }\end{array}$ & $\begin{array}{c}\text { Share in total } \\
\text { sample }\end{array}$ \\
\hline 22 & 111 & 20 & $18,0 \%$ & $16,8 \%$ \\
\hline 23 & 50 & 10 & $20,0 \%$ & $8,4 \%$ \\
\hline 24 & 33 & 3 & $9,1 \%$ & $2,5 \%$ \\
\hline 25 & 279 & 32 & $11,5 \%$ & $26,9 \%$ \\
\hline 26 & 43 & 5 & $11,6 \%$ & $4,2 \%$ \\
\hline 27 & 55 & 12 & $21,8 \%$ & $10,1 \%$ \\
\hline 28 & 128 & 24 & $18,8 \%$ & $20,2 \%$ \\
\hline 29 & 39 & 8 & $20,5 \%$ & $6,7 \%$ \\
\hline 30 & 10 & 1 & $10,0 \%$ & $0,8 \%$ \\
\hline 32 & 30 & 4 & $13,3 \%$ & $3,4 \%$ \\
\hline Total & 778 & 119 & $15,3 \%$ & $100,00 \%$ \\
\hline
\end{tabular}

Tab. 1. Characteristics of EMS 2018 sample 
Table 1 present the number of companies in our database, the number of responses in each included NACE C code, response rate for each NACE code and the distribution of manufacturing companies in the total sample of respondents. As seen, the largest NACE divisions are 25, 28 and 22. The response rates differ between NACE divisions; some of them are individually not representative. Nevertheless, 119 total responses in 2018 allowed certain statistical analysis.

Figure 2 presents the structure of manufacturing companies based on their size, where the number of employees was the classifying criterion. As already mentioned we have included in our survey only companies with 20 employees and more. The largest share of respondents is from medium sized companies and the share of large companies is quite similar to the small companies share.

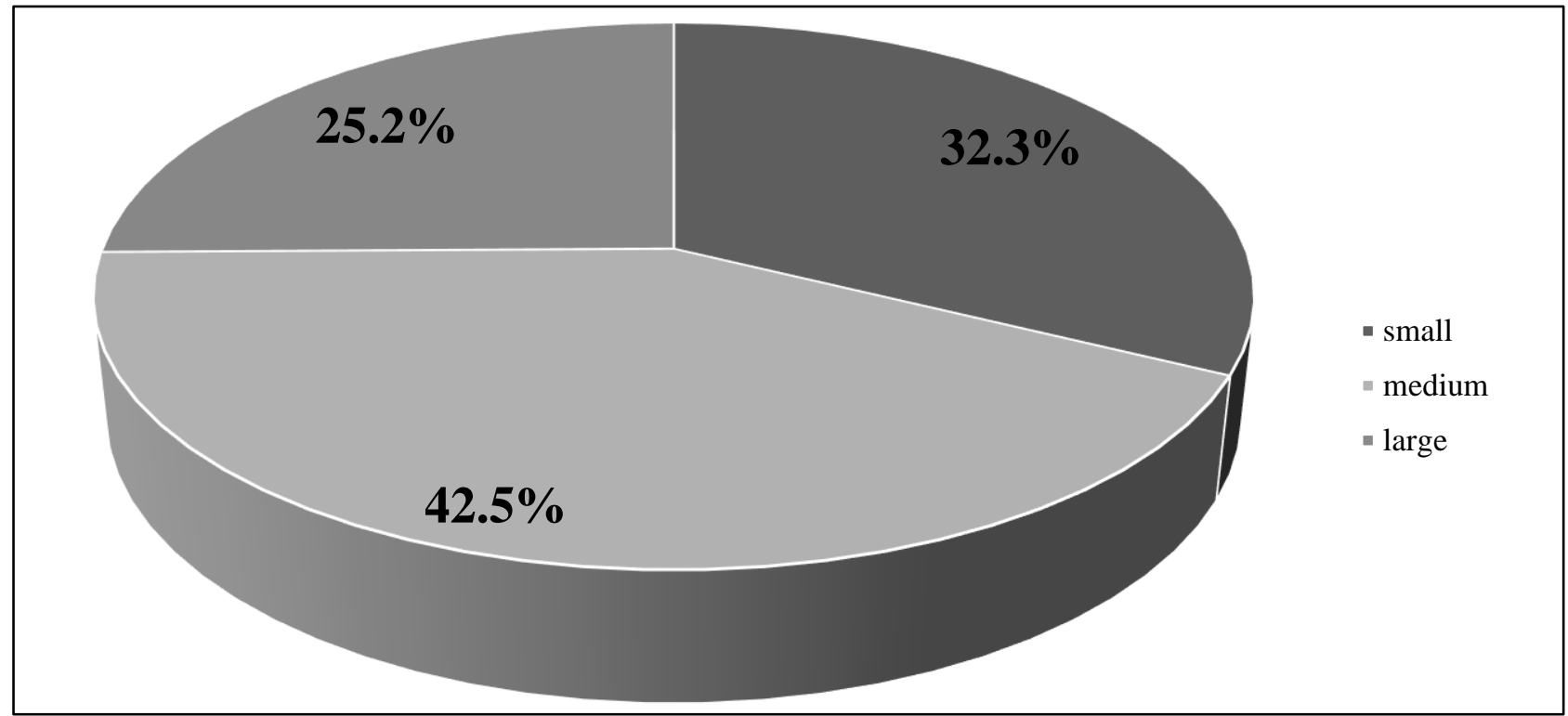

Fig. 2. Manufacturing companies based on their size in EMS 2018

We have divided manufacturing companies into two groups, based on their status as the final producer for consumers or business customers (OEM) or supplier (system supplier or supplier of parts or components). $46 \%$ of companies falls into supplier group and 54\% into OEM.

\section{Results and discussion}

\subsection{Organizational innovation concepts in EMS}

Figure 3 presents a structural part of question from EMS 2018 that deals with organizational innovation concepts. 


\begin{tabular}{|c|c|c|c|c|c|}
\hline $\begin{array}{c}\text { Use } \\
\text { planned } \\
\text { until } 2021\end{array}$ & no & Organizational concepts & yes & $\begin{array}{c}\begin{array}{c}\text { First used } \\
\text { (year) }\end{array} \\
-\end{array}$ & $\begin{array}{c}\begin{array}{c}\text { Extent of used } \\
\text { potential' }(\text { (l=low; } \\
m=\text { medium; } h=h i g h)\end{array} \\
\end{array}$ \\
\hline \multicolumn{6}{|c|}{ Organization of production } \\
\hline$\square$ & $\leftarrow$ & $\begin{array}{l}\text { Standardized and detailed work instructions } \\
\text { (e.g. standard operation procedures SOP, MOST) }\end{array}$ & $\rightarrow$ & $\frac{19}{20}$ & $\square \mathrm{m}$ \\
\hline$\square$ & $\leftarrow$ & $\begin{array}{l}\text { Measures to improve internal logistics (e.g. Value Stream Mapping/Design, } \\
\text { changed spatial arrangements of production steps) }\end{array}$ & $\rightarrow$ & $\frac{19}{20}$ & $\square \mathrm{b}$ \\
\hline & $\leftarrow$ & $\begin{array}{l}\text { Fixed process flows to reduce setup time or optimize change-over time } \\
\text { (e.q. SMED, QCO) }\end{array}$ & $\rightarrow$ & $19 / 20$ & $\square \mathrm{m}$ \\
\hline
\end{tabular}

Fig. 3. Question on organizational concepts in EMS 2018

For each organizational concept, we have asked for the following information:

- Use of organizational concept (yes/no).

- Use planned in the upcoming period of three years.

- Year in which organizational concept has been used for the first time in factory.

- Extent of actual utilisation compared to the most reasonable potential utilization in the factory: Extent of utilised potential "low" for an initial attempt to utilise, "medium" for partly utilised and "high" for extensive utilisation. High utilisation of an organizational concept means, for example, that it involves at least $70 \%$ of employees in the company.

In EMS 2018, we have divided 11 organizational concepts used in manufacturing companies into 3 groups:

- Organization of production (4 concepts);

- Management/controlling (5 concepts);

- Human resources (2 concepts).

In the next paragraph we give a short presentation of selected organizational innovation concepts. Standardized work is a detailed, documented and visual system by which associates develop and follow a series of predefined process steps. It should be used whenever the work requires completing a series of tasks. The detailed process steps which we call standardized work represent the current best practices for workers to follow in the completion of their jobs.

They are designed to minimize process variation introduced by the worker and to eliminate unnecessary motion. This reduces waste, eases problem solving and enhances productivity within a particular job or set of jobs (Krichbaum, 2008; Polašek and Šimon, 2018). Value stream mapping (VSM) is an important tool of the lean approach and is used to identify value-adding activities and those considered wasteful of materials and the flow of information and people (dal Forno, 2014; Mahendrakar, 2018). Value stream mapping is an enterprise improvement tool to help in visualizing the entire production process, representing both material and information flow (Singh et al., 2011).

In general VSM is can be also defined as a method proposed in the lean manufacturing approach in order to identify waste and improve performance (Stadnicka and Litwin, 2019). SMED - an acronym for "Single Minute Exchange of 
Die" - is a set of techniques belonging to lean manufacturing that aim to reduce the setup time of a machine. When properly applied, it allows machines to take less time to attach, giving more flexibility to the line (la Vega-Rodríguez, 2018).

Kanban is one of production pull principles. It is defined as a material flow control mechanism and it controls the proper quantity and proper time of the production of necessary products (Graves et al., 1995). Visual management is the framework to communicate expectations, performance, standards, and problems in a method that requires little to no time to understand. It is used on the factory floor, but it can be used in a variety of industries and environments. There is a significant number of quality assurance and quality management tools available.

Continuous improvement process assumes and requires that a team of experts together with the company leadership actively use quality tools in their improvement activities and decision making process (Sokovic et al., 2009). Six Sigma is an organization-wide approach used to specify exactly how organization managers set up and achieve objectives.

\begin{tabular}{|l|c|}
\hline \multicolumn{1}{|c|}{ Organizational concept } & $\begin{array}{c}\text { Share } \\
{[\%]}\end{array}$ \\
\hline Organization of production & \\
\hline $\begin{array}{l}\text { Standardized and detailed work instructions (e.g. standard operation procedures SOP, } \\
\text { MOST) }\end{array}$ & 79,7 \\
\hline $\begin{array}{l}\text { Measures to improve internal logistics (e.g. Value Stream Mapping/Design, changed } \\
\text { spatial arrangements of production steps) }\end{array}$ & 37,3 \\
\hline $\begin{array}{l}\text { Fixed process flows to reduce setup time or optimize change-over time (e.g. SMED, } \\
\text { QCO) }\end{array}$ & 36,4 \\
\hline $\begin{array}{l}\text { Production controlling following the Pull principle (e.g. KANBAN, Internal zero- } \\
\text { buffer principle) }\end{array}$ & 33,9 \\
\hline Management/controlling & \\
\hline $\begin{array}{l}\text { Display boards in production to illustrate work processes and work status (e.g. Visual } \\
\text { Management) }\end{array}$ & 52,5 \\
\hline $\begin{array}{l}\text { Methods of assuring quality in production (e.g. CIP, TQM, Six Sigma, preventive } \\
\text { maintenance) }\end{array}$ & 59,3 \\
\hline Certified quality standards (e.g. ISO 900x) & 83,9 \\
\hline Certified energy management system (e.g. EN ISO 50001) & 15,3 \\
\hline Certified environmental management system (e.g. EN ISO 14001) & 43,2 \\
\hline Human resources & \\
\hline $\begin{array}{l}\text { Instruments to promote staff loyalty (e.g. attractively designed responsibilities, learning } \\
\text { opportunities, flexible working hours, child care) }\end{array}$ & 67,8 \\
\hline $\begin{array}{l}\text { Employee training for skills (e.g. job rotation, organized exchange of experiences, } \\
\text { seminars) }\end{array}$ & 83,9 \\
\hline
\end{tabular}

Tab. 2. Organizational concepts adoption

It demonstrates how breakthrough improvements tied to significant bottom-line results can be achieved (Keller, 2005). ISO 9001, a quality management system standard developed by ISO (International Organization for Standardization), is a well established framework to manage processes. ISO 9000 is based on the principles of quality management, which views organizations as a set of inter-link end-to-end processes that includes customers and suppliers (Deming, 2000). ISO 14001 sets out 
the criteria for an environmental management system and can be certified to. It maps out a framework that a company or organization can follow to set up an effective environmental management system.

Employee loyalty is a complex, multifaceted construct that has been defined through numerous perspectives, including philosophical and psychological lens (Hart $\&$ Thompson, 2007). Some studies have defined employee loyalty as a behaviour, an attitude, a virtue or a combination of psychological traits and virtues (Masakure, 2016). Instruments to promote staff loyalty include attractively designed responsibilities, offering learning opportunities, flexible working hours, child care etc. The last organizational innovation concept described is employee training for skills, which have many different forms, such as job rotation, organized exchange of experiences, seminars.

In EMS 2018 we have reduced the number of organizational concepts we decided to analyse. Over the years we found out that the adoption rate of many studied organizational concepts is already very high. Therefore, we skipped organizational concepts, such as teamwork in production, integration of tasks, training of employees for creativity etc. All 11 organizational concepts and their adoption rate are presented in Table 2. As we can see only the concept "Certified energy management system (e.g. EN ISO 50001)" has a very low adoption rate (around 15\%). Therefore, we included only the other 10 organizational concepts in further analysis.

\subsection{Characteristics of organizational innovation concepts}

Table 3 presents 10 most frequently used organizational concepts together with data on first implementation of organizational concepts and planned use of specific organizational concepts in the period 2019-2021.

\begin{tabular}{|c|c|c|c|}
\hline Organizational concept & $\begin{array}{c}\text { Share } \\
{[\%]}\end{array}$ & $\begin{array}{c}\text { Year of } \\
\text { introduction }\end{array}$ & $\begin{array}{l}\text { Planned } \\
\text { use [\%] }\end{array}$ \\
\hline ISO 900x & 83,9 & 2003 & 15,8 \\
\hline Training of employees & 83,9 & 2005 & 26,3 \\
\hline Standardised instructions for work & 79,7 & 2002 & 20,8 \\
\hline Instruments for promoting staff loyalty & 67,8 & 2005 & 18,4 \\
\hline CIP, TPM, TQM, Six Sigma & 59,3 & 2009 & 29,2 \\
\hline Display boards in production (Visual Management) & 52,5 & 2012 & 41,1 \\
\hline EN ISO 14001 & 43,2 & 2007 & 34,3 \\
\hline Value Stream Mapping & 37,3 & 2010 & 16,2 \\
\hline SMED & 36,4 & 2011 & 34,7 \\
\hline Production controlling following pull principle & 33,9 & 2011 & 20,5 \\
\hline
\end{tabular}

Tab. 3. Characteristics of used organizational concepts

Both concepts from "Human resources" group have very high adoption rate in manufacturing companies. The age of Industry 4.0 and fast technological pace require that all employees acquire new knowledge and skills in different areas. They are also becoming more and more priceless and scarce, therefore companies must introduce 
specific instruments to promote staff loyalty (e.g. attractively designed responsibilities, offering learning opportunities, flexible working hours, childcare etc.). Quality standards, such as ISO 9001, have always had a high adoption rate, as they are prerequisite to conduct business in global economy. The pressure of environmental challenges in front of us requires also introduction of specific certified environmental management systems (e.g. EN ISO 14001). As many companies introduced specific organizational concepts in the last few years, the average year of first introduction of organizational concepts differs from previous EMS rounds. Except for Standardized instructions for work, all other three organizational concepts from "Organization of production" group are among the youngest, as well as Visual management from the "Management/controlling" group.

The column "Planned use" presents share of companies that do not possess a specific organizational concept, but are planning to introduce it in the period from 2019 to 2021. We can see that the share of companies that are planning to invest in organizational concepts in the next 3 years is quite high. More than $40 \%$ of companies that do not use display boards in production is planning to introduce them by the year 2021. That environmental issues are important is clearly presented also by the fact that one third of companies without environmental systems will introduce them by the end of 2021. CIP and SMED methods are also planned in one third of companies that at the moment do not use them.

Next, we looked at the extent of potential use or actual utilization (low, medium, high) of 10 most frequently used organizational concepts (Figure 4). Both quality and environmental standards have a very high share of companies who claim a high use of the standard (around $80 \%$ claim to use them to full potential and with average grade of 2,8 for all analyzed companies that use them). As expected from the previous research standardized instructions for work are also used at a high level. There is an increase in share of companies that use visual management at the high level comparing to previous EMS rounds.

This means that different display equipment in production is becoming widely used and at the same, it delivers required results. Comparing to previous EMS rounds there is also an increase in the share of companies that use continuous improvement methods to more full potential. It can be seen that both concepts from "Human resources" are often used to a very low potential (in around 20\% of manufacturing companies). Pull principle, SMED and value stream mapping methods have the lowest average potential use grade of around " 2 ". 


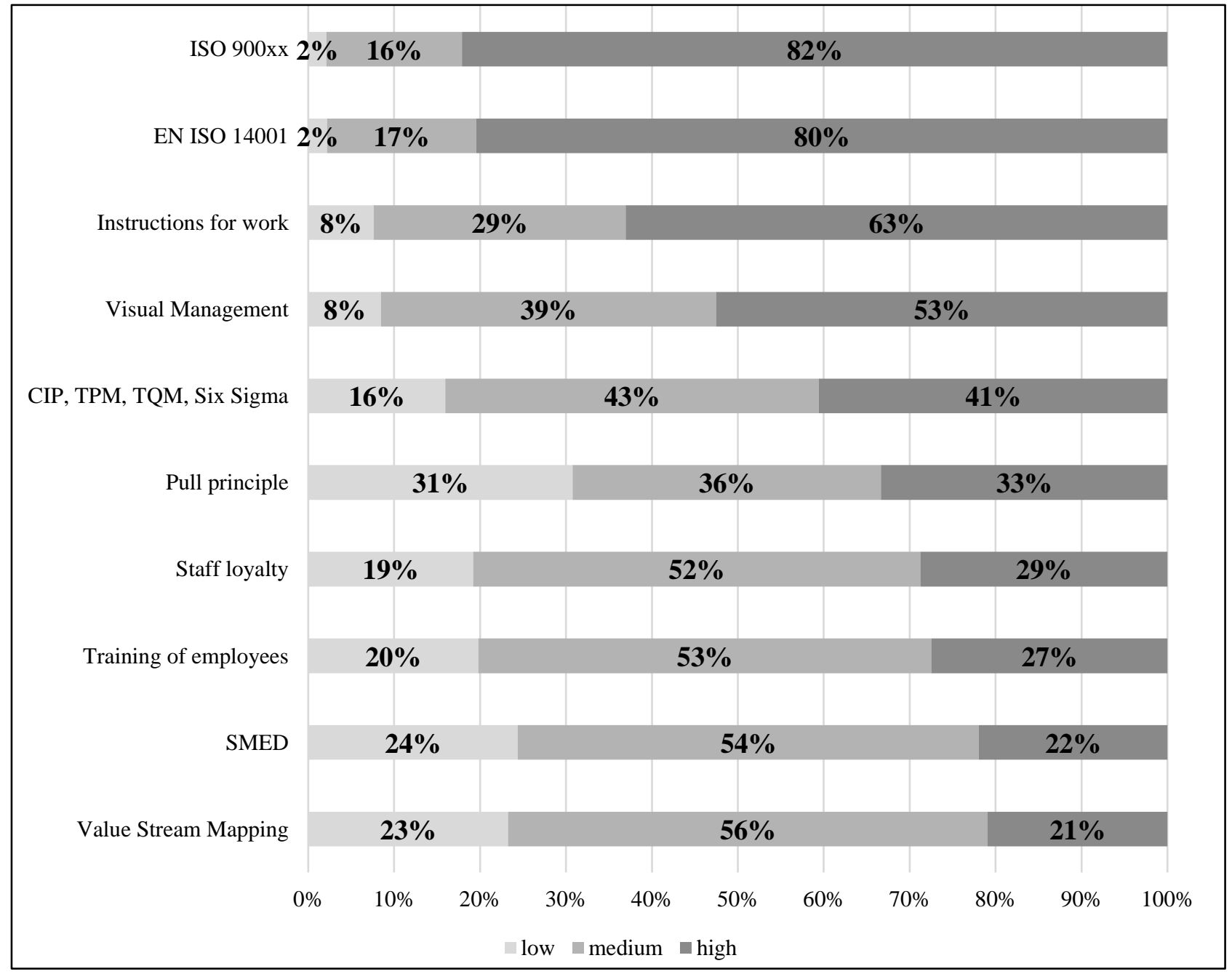

Fig. 4. Extent of use of selected organizational concepts

Figure 5 presents the use of analysed organizational concepts depending on company size. Large companies contribute the most to the dispersion of organizational concepts and the use of these concepts in medium-sized companies is similar to average use. In general, all large companies use ISO 9000 and EN ISO 14001 standards, instructions for work, methods of continuous improvement and have introduced instruments to promote staff loyalty and different employees training options. EN ISO 14001 standards are still rarely used in SMEs. Small companies very seldom introduce "Organization of production" concepts, such as value stream mapping, pull principles or SMED.

Figure 6 depicts the use of analysed organizational concepts depending on industry intensity. We have analysed the characteristics of manufacturing companies according to the OECD's taxonomy of manufacturing industries classified by their technological intensity [7]. We have formed two groups:

- Low and Medium-Low technology (LMT) with companies from NACE 22, 23, 24, 25 and 32 and;

- Medium-High and High technology (MHT) with companies from NACE 26, 27, 28,29 and 30. 


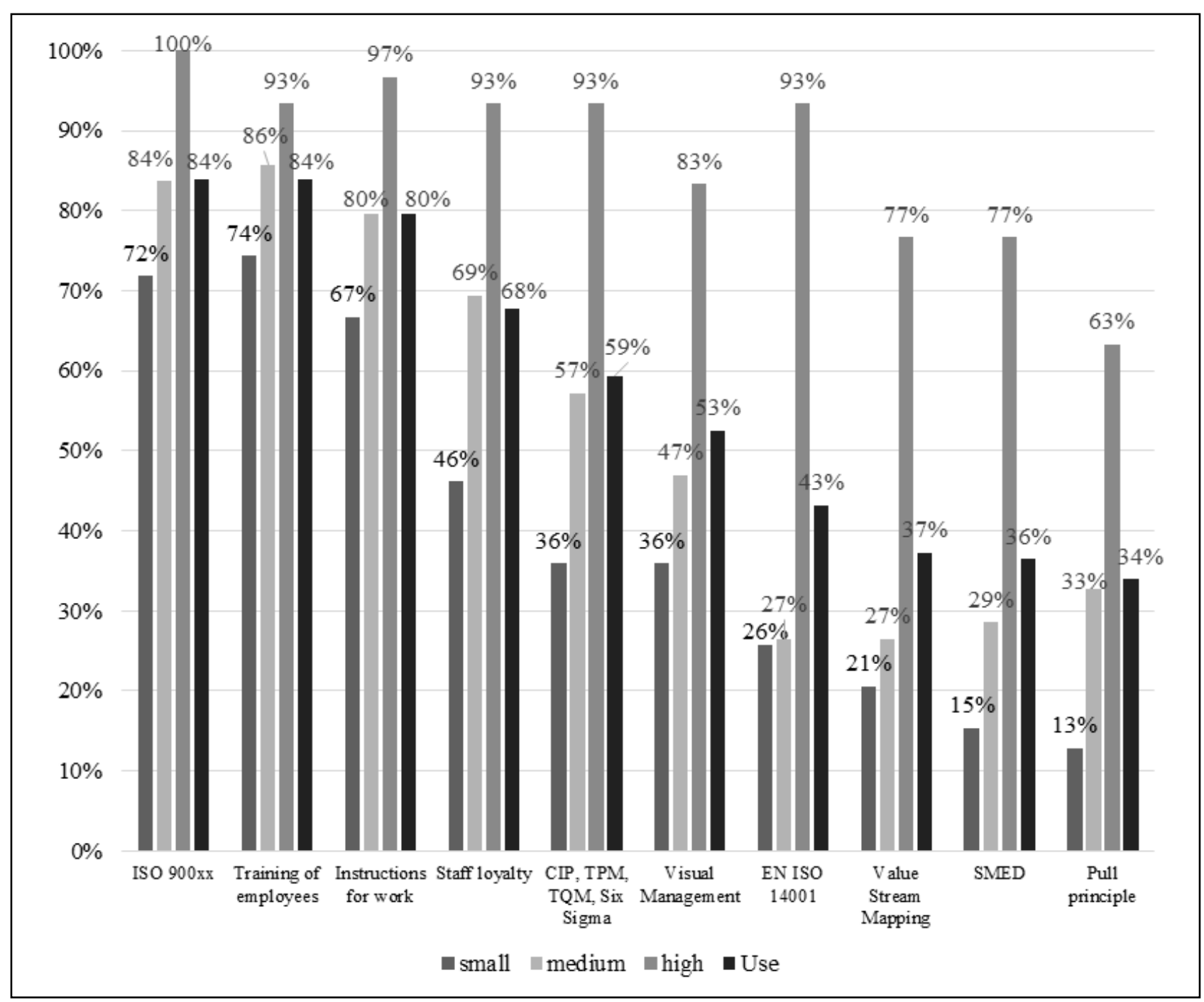

Fig. 5. Share of organizational concept use depending on company size

LMT companies have a 59\% share and MHT companies $41 \%$ share. Comparing to previous EMS rounds we can observe a slight change in adoption of organizational concepts in LMT and MHT companies.

It is clear that all analysed organizational concepts use is higher in medium and high technology industries. The difference is not very big, except for value stream mapping, pull principle, SMED and continuous improvement methods.

This could easily indicate that investments in high technology also require different organizational concepts that complement advanced manufacturing technologies. On the other side, it is possible to argue that MHT companies use the same advanced manufacturing technologies to fuller potential if they complement them with important organizational concepts. 


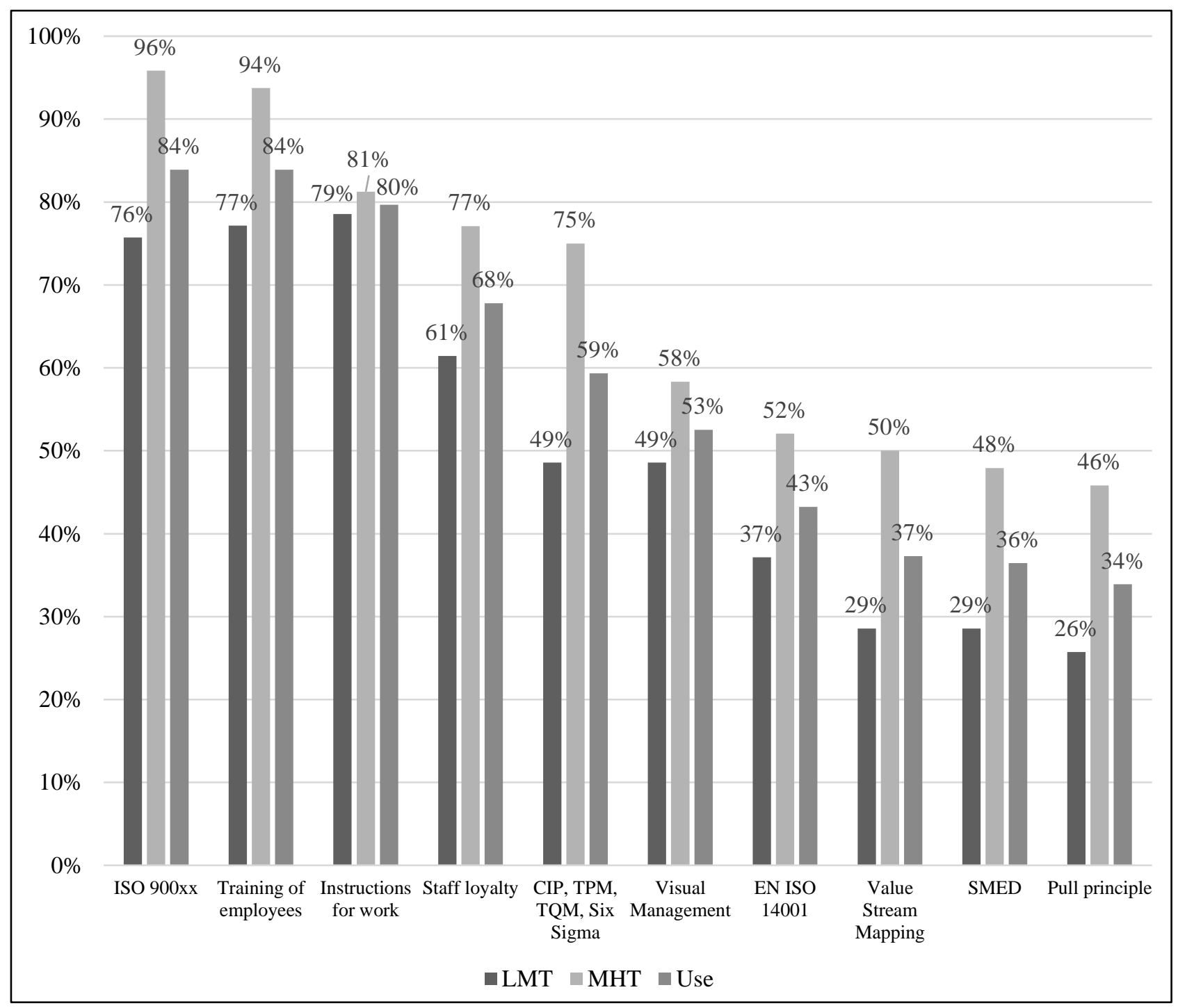

Fig. 6. Share of organizational concept use depending on technological intensity

We have divided manufacturing companies into two groups, based on their status as the final producer for consumers or business customers (OEM) or supplier (system supplier or supplier of parts or components). $46 \%$ of companies were suppliers and $54 \%$ OEM.

Figure 7 presents the use of analysed organizational concepts depending on OEM or supplier status. The results are similar as in EMS previous rounds, where in general the adoption of organizational concepts is a bit higher in supplier companies.

We can argue that Slovenian suppliers are part of global value networks and as such, they have to use specific organizational concepts to cooperate with global companies. 


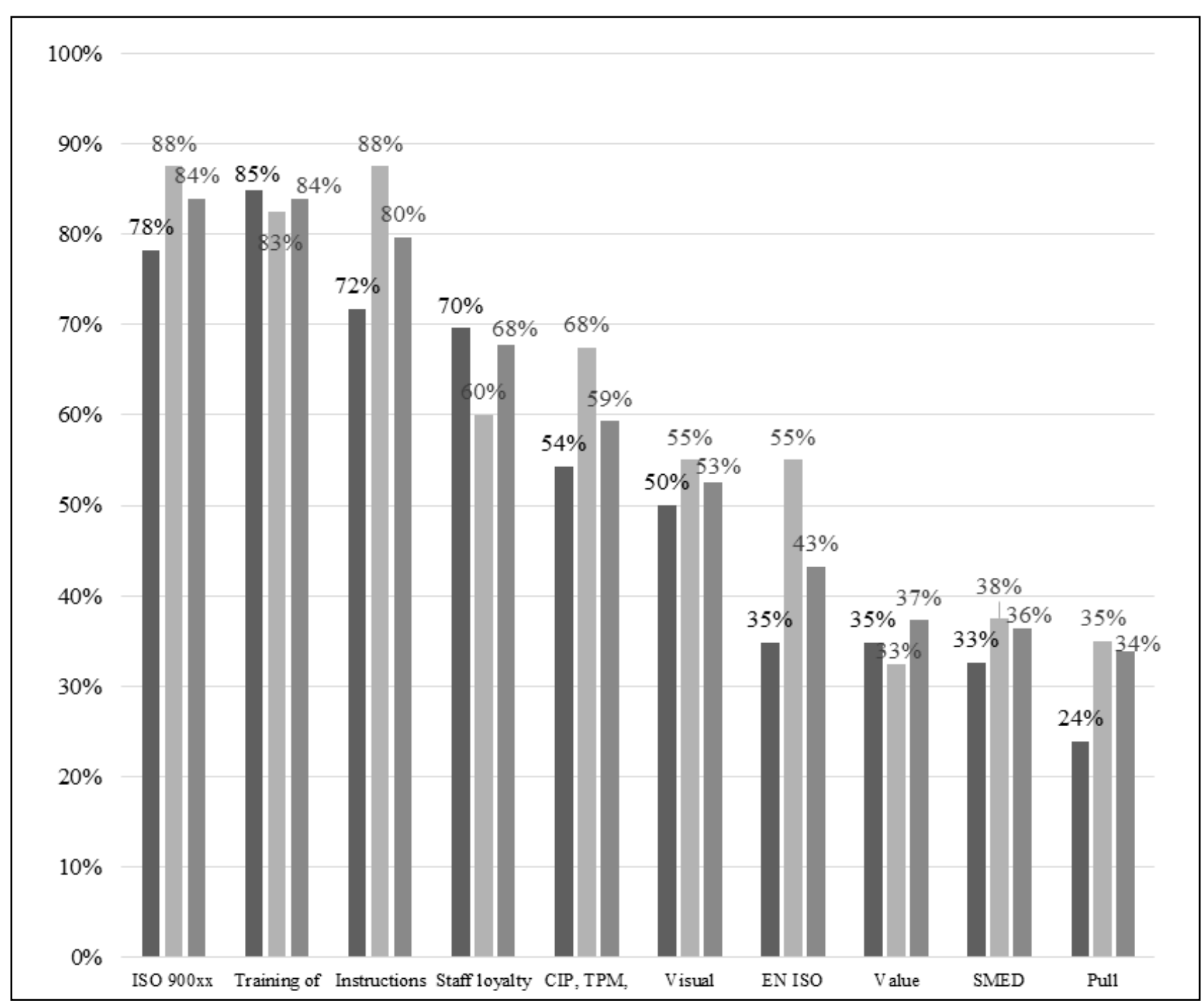

Fig. 7. Share of organizational concept use depending on OEM or supplier status

\section{Discussion and conclusion}

As we already mentioned, presented results are from the fifth and sixth EMS research round. This fact enables monitoring of specific organizational innovation concepts through the years and recognize some trends. Two of the concepts are observed throughout the period 2004-2016.

The importance of teamwork is not diminishing at it keeps its share of use at about $80 \%$. The concept of task integration (planning, operational and control functions in connection with the machine operator) was implemented in approximately $45 \%$ of manufacturing companies at the beginning of the observed period, but now the share has increased to almost $70 \%$. This is certainly affected by the expansion of informationcommunication technologies to support production processes.

Figure 8 presents comparison of eight organizational concepts that were included in EMS 2015 and 2018 round. We can see that there are no important differences between the adoption of seven of selected organizational concepts, except for instruments to promote staff loyalty from the "Human resources" group. This finding 
could indicate that skilled employees are becoming a scarce resource and that manufacturing companies have to introduce instrument from human resource management in order to keep the existing employees and to attract new workforce.

On the other hand, companies must motivate employees for continuous education and training, development of their skills and competences in order to cope with the requirements of fast technological advancement and new business reality.

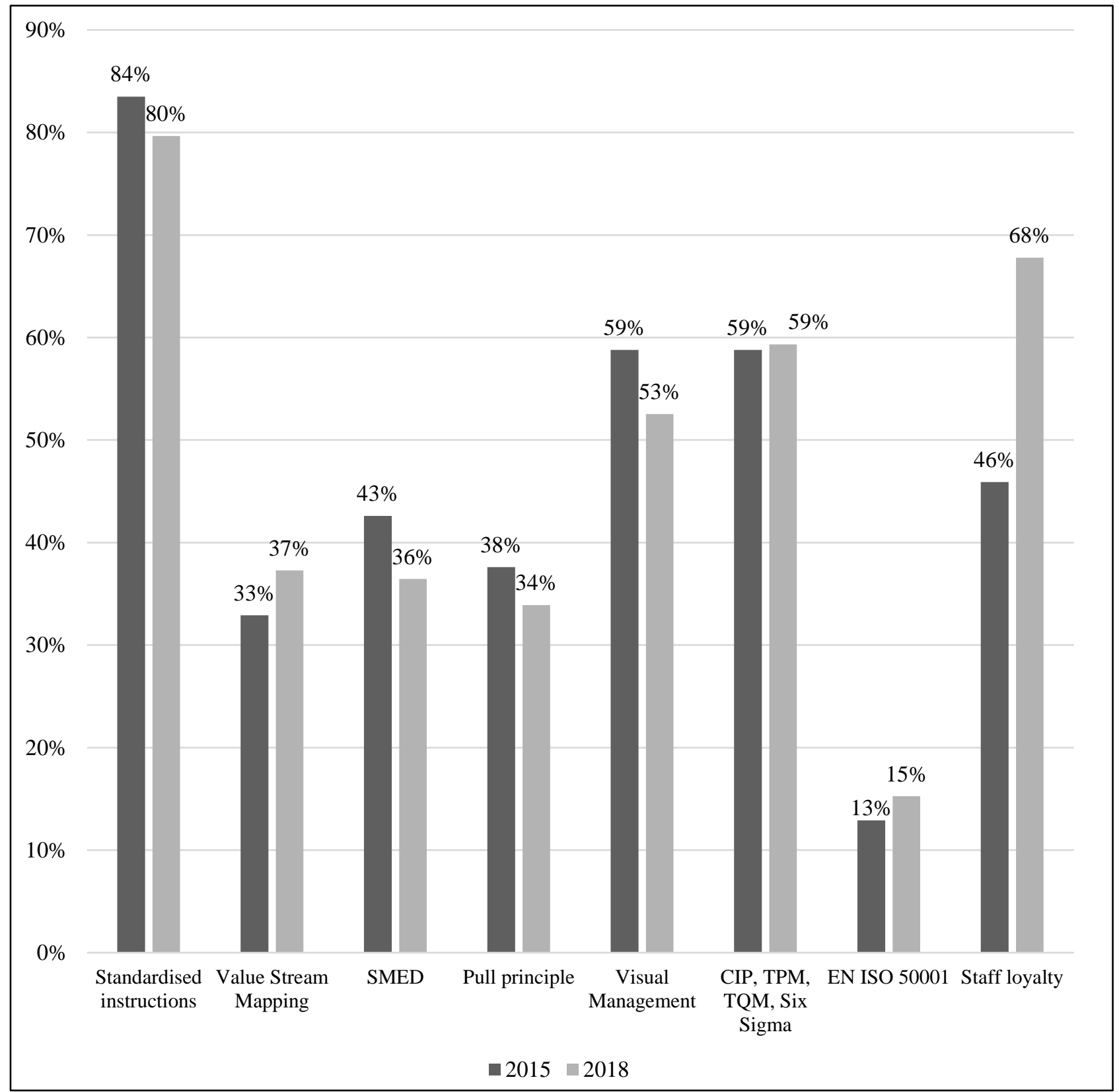

Fig. 8. Comparison of EMS 2015 and EMS 2018 organizational concepts use

Our research analysis has shown some interesting and important findings in the use of organizational concepts used by manufacturing companies and certain characteristics of companies.

There is a big difference in the exploitation of organizational concept potential. This is quite expected as all presented organizational innovation concepts are not 
necessary or suitable for every manufacturing company. Our research clearly shows that the use of all presented organizational innovation concepts is highly corelated with company size. Large companies have much higher share of use for all concepts.

In majority of cases there is also substantial difference between medium-sized and small companies. Average year of introduction of organizational innovation concepts depends on general age of these concepts. The ones with earlier average year of introduction have on the other hand higher level of exploiting its potential use. The "youngest" organizational innovation concepts have the most potential to improve their extent of use.

These concepts are also among those, where the most companies plan to introduce these concepts (e.g. VSM, SMED). Organizational concepts are more frequently present in supplier companies, but the difference to OEMs is not huge. In the past technological intensity of the industry did not play any role in organizational concepts adoption, but lately it seems that organizational concepts are more frequently adopted in medium-and-high industries.

As is the case with all research, some issues have to be taken into account when considering the reliability, significance, and generalities of the results obtained. Analysed data is from one country containing 119 companies. Although the sample is not small, further research should go towards the direction of a larger sample of more countries with different levels of development and also different strategies in terms of implementation of specific organizational concepts.

In the future, we will extend our research to other countries within our consortium with the aim of comparing the situation in Slovenian manufacturing companies to companies in Western European and Eastern European countries.

\section{Acknowledgements}

The authors acknowledge the financial support from the Slovenian Research Agency (research core funding No. P2-0190).

\section{References}

Armbruster, H., Bikfalvi, A., Kinkel, S. \& Lay, G. (2008). Organizational innovation: The challenge of measuring non-technical innovation in large-scale surveys, Technovation, Vol. 28, No. 10, pp. 644-657

Dachs, B.; Kinkel, S.; Jäger, A. \& Palčič, I. (2019). Backshoring of production activities in European manufacturing. Journal of purchasing and supply management, Vol. 23, No. 3

Dal Forno, A. J.; Pereira, F. A.; Forcellini, F. A. \& Kipper, L. M. (2014). Value Stream Mapping: a study about the problems and challenges found in the literature from the 
past 15 years about application of Lean tools, International Journal of Advanced Manufacturing Technology, Vol. 72, pp. 779-790

Damanpour, F. (2014). Footnotes to Research on Management Innovation, Organization Studies, Vol. 35, No. 9, pp. 1265-1285

Deming, W. E. (2000). The new economics: For industry, government, education, MIT Press, Boston

Gallego, J.; Rubalcaba, L. \& Hipp, C. (2012). Organizational innovation in small European firms: A multidimensional approach, International Small Business Journal Vol. 31, No. 5, pp. 563-579

Graves, R.; Konopka, J. M. \& Milne, R. J. (1995). Literature review of material flow control mechanisms, Production Planning and Control, Vol. 6, No. 5, pp. 395-403

Keller, P. (2005). Six Sigma Demystified - a self teaching guide, McGraw-Hill, New York

Hart, D. W. \& Thompson, J. A. (2007). Untangling employee loyalty: A psychological contract perspective, Business Ethics Quarterly, Vol. 17, No. 2, pp. 297-323

Krichbaum, B. D. (2008). Standardized Work: The Power of Consistency, Process Coaching Inc.

Kocijančič, T., Bikfalvi, A., Llach Pages, J. \& Palčič, I. (2013). Impact of innovative organisational concepts adoption on manufacturing firms' performance. Proceedings of Operations management at the heart of the recovery: collection of presented papers at EurOMA 2013, 20th EurOMA Conference, 7th-12th June 2013, Dublin, Ireland la Vega-Rodríguez, M. D.; Baez-Lopez, Y. A. Flores, D. L.; Tlapa, D. A. \& AlvaradoIniesta, A. (2018). Lean Manufacturing: A Strategy for Waste Reduction, Proceedings of New Perspectives on Applied Industrial Tools and Techniques, Springer, Cham, pp. 153-174

Mahendrakar, S.R. (2018). Research issues and development in advance manufacturing systems, In: DAAAM International Scientific Book 2018, Katalinic, B. (Ed.), 141-152, DAAAM International Vienna, ISBN 978-3-902734-19-8, Vienna (Austria)

Masakure, O. (2016). The effect of employee loyalty on wages, Journal of Economic Psychology, Vol. 56, pp. 274-298

OECD. (2005). Oslo manual. Guidelines for collecting and interpreting innovation data: 3rd edn., OECD EUROSTAT, Paris

OECD. (2018). Oslo manual. Guidelines for collecting, reporting and using data on innovation: 4th edn., OECD EUROSTAT, Paris

Polašek, P. \& Šimon, M. (2018). Product innovation influence on production organization, Proceedings of $29^{\text {th }}$ DAAAM, Katalinic, B. (Ed.), pp. 548-552, ISBN 978-3-902734-20-4, Zadar (Croatia), October 2018, DAAAM International Vienna Sartal, A.; Llach, J.; Vázquez, X. H. \& de Castro, R. (2017). How much does Lean Manufacturing need environmental and information technologies?, Journal of Manufacturing Systems, Vol. 45, pp. 260-272 
Palcic, I.; Ojstersek, R. \& Buchmeister, B.: Organizational Innovation Concepts in ...

Singh, B.; Garg, S. K. \& Sharma, S. K. (2011). Value stream mapping: literature review and implications for Indian industry, International Journal of Advanced Manufacturing Technology, Vol. 53, No. 5-8, pp. 799-809

Stadnicka, D. \& Litwin, P. (2019). Value stream mapping and system dynamics integration for manufacturing line modelling and analysis, International Journal of Production Economics, Vol. 208, pp. 400-411 